\title{
Biyoloji Öğretmen Adaylarının Ders Çalışma Becerilerinin İncelenmesi*
}

\section{Examination of Prospective Biology Teachers' Study Skills}

\section{Esra ÖZAY-KÖSE**}

Received: 08 March 2018

\section{Şeyda GÜL ${ }^{* * *}$}

Research Article

\section{Mehmet ERKOL ${ }^{* * * *}$}

Accepted: 20 September 2018

ABSTRACT: The purpose of this research is to examine the prospective biology teachers' study skills and to compare in terms of gender. The sample of the study, which was implemented with survey method, consisted of 62 (40 females, 22 males) prospective biology teachers studying in Education Faculty of Ataturk University. For determining the teachers' study skills, the data were collected through "Study Skill Questionnaire (SSQ) originally developed by Bay, Tuğluk and Gençdoğan (2004). The five-point Likert type SSQ included in totally 26 items with three sub-dimensions: (1) motivation (2) time management (3) preparation for exams-test anxiety. Cronbach's Alpha for the overall scale was calculated as 0.729 . The findings obtained from data analyzed by SPSS.18 indicated that the prospective biology teachers had low level of study skills for all subdimensions of the SSQ. Additionally, the findings for overall SSQ showed that there was not a statistically important difference between genders. As a result, recommendations were suggested towards development of the prospective teachers' study skills.

Keywords: study skills, prospective biology teachers, gender.

ÖZ: Bu çalışmanın amacı, biyoloji öğretmen adaylarının ders çalışma becerilerini belirlemek ve cinsiyet açısından karşılaştırmaktır. Tarama yöntemi ile yürütülen çalışmanın örneklem grubunu, Atatürk Üniversitesi K. K. Eğitim Fakültesi’nin biyoloji eğitimi anabilim dalında öğrenim gören toplam 62 öğretmen adayı (40 kadın, 22 erkek) oluşturmaktadır. Öğretmen adaylarının ders çalışma becerilerini belirlemek için daha önce Bay, Tuğluk ve Gençdoğan (2004) tarafindan hazırlanan Ders Çalışma Becerileri Anketi (DÇBA) kullanılmıştır. DÇBA 3 alt boyut içeren 5'li Likert tipi 26 maddeden oluşmaktadır. Alt boyutlar, (1) motivasyon, (2) zaman yönetimi (3) sınavlara hazırlanma-sınav kaygısı şeklinde adlandırılmıştır. Ölçeğin geneli için Cronbach's Alpha güvenirlik katsayısı 0.729 olarak hesaplanmıştır. Elde edilen veriler SPSS.18 istatistik programında analiz edilmiştir. Analiz sonucunda elde edilen bulgular incelendiğinde, öğretmen adaylarının büyük bir çoğunluğunun her alt boyutta ders çalışma becerileri konusunda eksikliklerinin olduğu görülmektedir. Ayrıca öğretmen adaylarının ders çalışma becerileri ile cinsiyet düzeyi açısından anlamlı bir farkın olmadı̆̆ı görülmüştür. Çalışmanın sonunda ise öğretmen adaylarının ders çalışma becerilerinin geliştirilmesine yönelik önerilerde bulunulmuştur.

Anahtar kelimeler: ders çalışma becerileri, biyoloji öğretmen adayları, cinsiyet.

\footnotetext{
* A part of this study was presented at "International Congress on Science and Education-2018" as oral presentation.

** Corresponding Author: Prof. Dr., Atatürk University, Erzurum, Turkey, esraozay@atauni.edu.tr

*** Assoc. Prof. Dr., Atatürk University, Erzurum, Turkey, seydagul@ atauni.edu.tr

***** Asst. Prof. Dr., Afyon Kocatepe University, Afyonkarahisar, Turkey, merkol20@ hotmail.com
}

\section{Citation Information}

Özay-Köse, E., Gül. Ş., \& Erkol, M. (2018). Biyoloji öğretmen adaylarının ders çalışma becerilerinin incelenmesi. Kuramsal Eğitimbilim Dergisi [Journal of Theoretical Educational Science], UBEK-2018, 24-40. 


\section{Giriş}

Günümüzde biyoloji bilimine verilen önem kuşkusuz her geçen gün daha da artmaktadır. Bu durum ise biyoloji derslerinin, eğitimin tür ve her kademesinde diğer fen dersleri kadar önemli derecede yer almasına sebep olmaktadır (Güler \& Sağlam, 2002). Öte yandan biyoloji biliminin oldukça geniş kapsamlı olması nedeniyle fazla sayıda ve soyut konular içermesi, ayrıca öğrenciler için bazı biyoloji kavramlarının kolay anlaşılabilir olmaması sebebiyle bu ders birçok öğrenci tarafindan zor derslerden birisi düşünülmektedir. Nitekim alan yazın incelendiğinde, bu konu ile ilgili olarak yapılan birçok araştırmada biyoloji derslerinin, öğrencilerin düşük başarı sergiledikleri, öğrenme güçlüğü çektikleri ve bu nedenle pek çok kavram yanılgısına sahip oldukları derslerin başında geldiği ileri sürülmektedir (Chuang \& Cheng, 2003; Gül, 2011; Sebitosi, 2007; Staeck, 1995; Thompson \& Logue, 2006). Biyoloji konular1 ile ilgili alan yazında ortaya konulan zorlukların sebebine yönelik birçok araştırma yapılmıştır. $\mathrm{Bu}$ araştırmaların sonuçlarına göre zorluk sebepleri; içerdiği kavramların soyut olması, dersi yürüten öğretmenlerin çoğu kez ders kitaplarına bağlı kalarak dersleri düz anlatım yöntemiyle işlemeleri nedeniyle biyoloji dersinin öğrenciler tarafindan ezber derslerden biri olarak görüldüğü, bu ezbercilik durumunun ise biyoloji derslerindeki başarının düşmesine neden olduğu şeklinde siralanmaktadır (Akpınar, 2006; Kılıç \& Sağlam, 2004; Tekkaya, Çapa, \& Y1lmaz, 2000; Yaman \& Soran, 2000).

Öğrencilerin dersteki başarılarını olumlu veya olumsuz etkileyen nedenlerden biri de ders çalışma becerileridir. Alan yazında farklı araştırmacılar tarafından ders çalışma becerileri ile ilgili farklı biçimlerde ifade edilmiş tanımlamalar mevcuttur. Örneğin bir grup araştırmacıya göre ders çalışma becerileri, öğrencinin gerekli bilgileri öğrenebilmesi için yapması gerekenleri planlaması, bunları organize etmesi ve bilgiyi kodlaması adımlarını içeren bir süreç olarak ifade edilmiştir (Rafoth \& DeFabo, 1990). Diğer taraftan Thomas (1993) aynı süreci, bilgiyi edinme ve öğrenme amaciyla belirli bazı tekniklerin etkili bir şekilde kullanılması olarak tanımlamıştır. Uluğ'a (1981) göre ise ders çalışma becerileri, öğrencinin belli bir program dâhilinde düzenli ve sistemli olarak derslerini çalışması, bunu yaparken dikkatini derse yoğunlaştırması ve öğrenmeye yönelik görevlerini tamamlayıncaya kadar çalışmalarını yürütmesi olarak tanımlamıştır. Her ne kadar farklı araştırmacılar tarafından farklı biçimlerde tanımları yapılsa da ders çalışma becerileri kapsamında yer alan davranışlar motivasyon, zaman yönetimi ve sınavlara hazırlanma-sınav kaygısı yönetimi olmak üzere üç grup altında toplanmaktadır (Bay, Tuğluk, \& Gençdoğan, 2005; İlhan, Çetin, \& Sünkür, 2013).

Martin (2001) motivasyonu, öğrencilerin başarıya ulaşması, okulda düzenli olarak çalışmaları ve öğrenmeleri için tetikleyici bir güç olarak tanımlamıştır. Öte yandan başka bir araştırmacı tarafından; öğrencilerin başarılı olmalarını sağlamada önemli bir unsur olarak kabul edilen motivasyon, genel olarak "insan davranışlarının ortaya çıkmasına sebep olan ve davranışlara yön veren içsel durum" biçiminde tanımlanmıştır (Ertem, 2006).

Ders çalışma becerilerinin ikinci boyutu olan zaman yönetimi, iş gücü yoğunluğu, hayati önem taşıyan öncelikli işler arasında yer belirleme ve bunları sonuçlandırmak için yöneltme, belirli bir süreyi etkili bir biçimde kullanabilme yeteneği olarak tanımlanmaktadır (Açıkalın, 1994; Efil, 2000). Zaman yönetimini etkili kullanmanın bazı olumlu sonuçları olabilmektedir. Bunlardan ilki verimlilikle ilgili 
sonuçlardır. Bu konu ile ilgili örneğin, zamanı etkili bir biçimde yönetebilen kişiler daha iyi performans gösterebilirler ve böylece onların verimliliği de artar. Bu durum ise hem kişiye hem de örgüte fayda sağlar. Zaman yönetimini etkili kullanmanın ikinci sonucu ise, olumlu psikolojik sonuçlar vermesidir (Demirtaş \& Özer, 2007).

Ders çalışma becerileri ile ilgili üçüncü boyut, sınavlara hazırlanma-sınav kaygısı yönetimidir. Fen bilimlerinde yapılan sınavların çoğunlukla öğrencilerin ezber yoluyla edindikleri bilgileri ölçmek amacıyla yapıldığı görülmektedir (Erözkan, 2004; Güneri, 1996). Bu durum, okullarda çoğunlukla ezbere dayalı bir eğitimin hâkim olduğunu göstermektedir. Bunun sonucu olarak ise öğrenciler okullarında öğrendiği bilgileri anlamlı hale getirmeksizin ezber yoluna gitmekte ve bu bilgileri günlük yaşamla ilişkilendirmede yetersiz kalmaktadırlar (Ünal \& Ergin, 2006). Sınav kaygısı yüzünden öğrenciler bazen sahip olduğu potansiyeli ortaya koyamamakta, bazen de bu durum öğrenimlerini tamamlayamamalarına sebep olmakta, onların geleceğe dair yaşam tercihlerini ve mesleki kararlarını olumsuz etkileyebilmektedir (Bilge \& Pektaş, 2004; Softa, Karaahmetoğlu, \& Çabuk, 2015). Benzer şekilde Campbell (2003) ile Christenson ve Thurlow (2004) da fen, matematik ve diğer alanlarda öğrencilerin sinav kaygısına bağlı olarak daha düşük başarı göstermesinin akademik başarısızlık problemine ve buna bağlı olarak okulu bırakma problemine dikkat çekmiştir. Bu açıdan sınavlara yönelik kaygı düzeyi yüksek olan öğrenciler, bilişsel yeteneklerini yeterli düzeyde ortaya koyamadıklarından, düşük statüde olan, değerlendirme ve rekabet gücü fazla olmayan meslekleri daha fazla tercih etme yoluna gitmektedirler (Ergene, 1994; Özay-Köse, Diken, \& Gül, 2017).

Öğrencilerin ders çalışma becerileri ile ilgili yapılmış çalışmalar mevcut olmakla birlikte, bu çalışmalar da genel bir şekilde ortaöğretim ve üniversite öğrencileri üzerinde değerlendirmeler yapılmıştır (Bay, Tuğluk, \& Gençdoğan, 2004; İlhan ve diğerleri, 2013; Topkaya, Yaka, \& Öğretmen, 2011; Yı1maz \& Orhan, 2011). Buna karş1lı ezber ve çok sayıda soyut kavramı içeren biyoloji bölümü öğrencileri/öğretmen adayları için yapılan çok fazla çalışmaya rastlanılmamıştır. Ayrıca eğitim sisteminin en önemli hedeflerinden birinin öğrencilerin öğrenme ve çalışma alışkanlığını kazanmalarını sağlamak olduğu düşünüldüğünde, bu hedefi gerçekleştirmek için öğretmenlerin, öğrencilerinin sahip olduğu ders çalışma alışkanlıklarının nasıl olduğunu iyi bilmeleri ve öğrencilerinin özelliklerini iyi tanımaları gerekmektedir (Durukan, 2015; Taşpınar, 2007). Bu noktada geleceğin öğretmenleri olacak öğretmen adaylarının kendilerinin de verimli ve etkili çalışma stratejileri ile olumlu tutumlara sahip olmaları, öğrencilerinin de daha etkili çalışma becerilerine sahip olmalarına ve ders çalışmaya yönelik daha pozitif tutum geliştirmelerine çok önemli katkılar sağlayabilir (Erdamar, 2010). Bu nedenlerle yapılan çalışmanın önem taşıdığı düşünülmektedir. Bu noktadan hareketle bu çalışmanın amacı, biyoloji öğretmeni adaylarının ders çalışma becerilerini belirlemek ve cinsiyet açısından karşılaştırmaktır.

\section{Yöntem}

Bu çalışma tarama modelinde yapılmıştır. McMillan ve Schumacher'in (2010) de ifade ettiği gibi tarama çalışmaları nicel araştırma desenlerinden birisi olup, bu modeli kullanan araştırmacılar, belirledikleri çok geniş bir örneklem grubuna veri toplama sürecinde anket/ölçek uygular ya da görüşmeler yapar. Bilindiği gibi bu süreçte sıklıkla tercih edilen anket veya ölçekler, özellikle eğitim araştırmalarında araştırmaya 
dahil edilen örneklem grubunun tutum, inanç, görüş veya özelliklerini belirlemek ya da belirli bir konu ile ilgili bilgi toplamak amacıyla sıklıkla kullanılmaktadır.

\section{Örneklem}

Çalışmanın örneklem grubu Atatürk Üniversitesi Eğitim Fakültesi’nde biyoloji eğitimi anabilim dalında okuyan 62 (40 kadın, 22 erkek) biyoloji öğretmen adayı oluşturmaktadır. Örneklem seçiminde, olasılığa dayalı örneklem seçim tekniklerinden biri olan basit tesadüfî örneklem seçiminden yararlanılmıştır.

\section{Veri Toplama Aracı}

Çalışmada kullanılan veri toplama aracı, Ders Çalışma Becerileri Anketi (DÇBA) adıyla daha önce Bay ve diğerleri (2005) tarafından geliştirilmiştir. DÇBA üç alt boyut içeren beş seçenekli Likert-tipi hazırlanmış 26 maddeden oluşmaktadır. Alt boyutlar; (1) motivasyon (1-11 maddeler), (2) zaman yönetimi (12-18 maddeler), (3) sınavlara hazırlanma-sınav kaygısı (19-26 maddeler) şeklinde adlandırılmıştır. DÇBA'nin puanlanması ise 1=Hiç katılmıyorum, 2=Katılmıyorum, 3=Kısmen katıliyorum, 4=Katıliyorum ve 5=Tamamen katıliyorum şeklindedir. Puan ortalamalarına ait aralıklar, Altunoğlu ve Atav'ın (2005) çalışmalarında ifade ettikleri şekilde: 1.00-1.79 hiç katılmıyorum; 1.80-2.59 az kat1lyorum; 2.60-3.39 orta derecede katılıyorum; 3.40-4.19 çok katılıyorum; 4.20-5.00 tamamen katıliyorum olarak tanımlanmıştır. Öte yandan DÇBA'nin Cronbach Alpha güvenlik katsayısı 0.729 olarak hesaplanmıştır. Tezbaşaran (1997) tarafindan Cronbach Alpha güvenirlik katsayısının 0.70 ve üzeri olmasının kabul edilebilir bir değer olduğu dikkate alındığında, 0.729 değerinin söz konusu ölçeğin yeterli düzeyde güvenilir olduğu söylenebilir.

\section{Verilerin Analizi}

Çalışmada verilerin analizi aşamasında betimsel istatistiklerden (aritmetik ortalama, standart sapma vb.) yararlanılmıştır. Ayrıca biyoloji öğretmen adaylarının ders çalışma becerileri anketinden elde edilen puanlarının cinsiyete göre farklılık gösterip göstermediğini ortaya koymak amacıyla, bağımsız örneklem t-testi yapmaya karar verilmiştir. Veriler araştırmacılar tarafından SPSS.18 paket programı kullanılarak analiz edilmiştir. İstatistik testler yapılmadan önce analiz sonuçlarını olumsuz etkileyebileceği düşünülen hususlara dikkat edilmiştir. $\mathrm{Bu}$ amaçla araştırmacılar tarafından veri girişinde kaçan veya yanlış girilen değerler olmamasına dikkat edilmiştir. Ayrıca, öğrencilerin anketteki maddeleri dikkatli okuyup işaretlemeleri, anlamadıkları yerde sormaları, boş bırakmamaları gibi telkinlerde bulunulmuştur. Böylece çalışmanın analiz güvenirliği sağlanmaya çalışılmıştır.

\section{Bulgular}

Çalışmada söz konusu katılımcıların DÇBA'dan elde edilen puanlarının gerek anketin geneli gerekse alt boyutları açısından analiz edilmesi sonucunda Tablo 1'de gösterilen bulgular elde edilmiştir. 


\section{Tablo 1}

Öğretmen Adaylarının DÇBA'ye Ait Puanlarının Ortalama ve Standart Sapmaları

\begin{tabular}{|c|c|c|c|}
\hline Madde & Boyutlar & $\bar{X}$ & ss \\
\hline & Motivasyon Boyutu & & \\
\hline 1 & Derse giderim ama dersi dinlemek yerine başka şeyler yaparım & 3.69 & 1.29 \\
\hline 2 & Dikkatim dağılmadan uzun süre oturup ders çalışamıyorum & 3.75 & 1.24 \\
\hline 3 & Çalışmaya başlayacağım zaman, kendimi çalışamayacak kadar yorgun hissediyorum 3 & 3.46 & 1.30 \\
\hline 4 & TV ya da müzik olmadan ders çalışamıyorum & 3.93 & 1.15 \\
\hline 5 & Ders çalışırken yanımda yiyecek bir şeyler bulunduruyorum & 3.50 & 1.38 \\
\hline 6 & Sevmediğim derslere karşı çalışma isteği duymuyorum & 3.37 & 1.26 \\
\hline 7 & Çoğunlukla uykumu tam olarak alamıyorum ve derse gittiğimde uyukluyorum & 3.98 & 1.14 \\
\hline 8 & $\begin{array}{l}\text { Bazı zamanlar televizyon seyrederken veya odada birileri konuşurken ders } \\
\text { çalışıyorum }\end{array}$ & 3.82 & 1.06 \\
\hline 9 & Yatak üzerinde uzanarak ders çalışmaktan hoşlanıyorum & 3.79 & 1.18 \\
\hline 10 & Kendi alanım dışındaki derslere (genel kültür vs.) çalışmaya önem vermiyorum & 3.19 & 1.36 \\
\hline \multirow[t]{2}{*}{11} & $\begin{array}{l}\text { Herhangi bir ders hakkında (Kolay bir ders, herkes geçiyor gibi) duyumlar edindiğim? } \\
\text { zaman o derse daha az çalışıyorum }\end{array}$ & 13.72 & 1.21 \\
\hline & Alt ortalama & 3.65 & 0.63 \\
\hline
\end{tabular}

Zaman Yönetimi Boyutu

13 Ders ile ilgili çalışmalarımı belirli bir plan dahilinde yapmıyorum $\quad 3.46 \quad 1.28$

14

Dersle ilgili çalışmalarımı günün belirli saatlerinde değil farklı zamanlarda $\quad 3.85 \quad 1.07$ yapıyorum

15 Bir başka derse geçmeden, diğer bir dersi bütünüyle tamamlamıyorum $\quad 3.20 \quad 1.43$

16 Bazı derslere o kadar çok zaman ayırıyorum ki diğer derslere zamanım kalmıyor $3.66 \quad 1.05$

17 Herhangi bir derse çalışırken konuyu öğrenmek için çok fazla zaman harcıyorum $\quad 2.62 \quad 1.27$

18 Zamanımı ders dışı etkinliklere (eğlence vs.) ayırırsam, ders çalışmak için zamanım $3.04 \quad 1.43$ kalmıyor, ya da ders çalışmaya ayırırsam ders dışı etkinlikler için zamanım kalmıyor

$\begin{array}{lll}\text { Alt ortalama } & 3.37 & 0.54\end{array}$

Sinavlara Hazırlanma-Sinav Kaygisı Boyutu

19 Sınavlarıma çalışıyorum ama sınava gittiğimde aklımda konuyla ilgili hiçbir şey $\quad 3.14 \quad 1.32$ kalmiyor

20 Konuyu çok iyi bildiğimi düşündüğüm zamanlarda bile sinavlarda pek çok konu $\quad 3.00 \quad 1.34$ (nokta) aklıma gelmiyor

21 Sinavlar art arda geldiği zaman önem vermediğim derslere daha az çalışıyorum $\quad 3.83 \quad 1.12$

22 Sınavının çok zor olacağını düşündüğüm dersim olduğu zaman diğer derslerin $\quad 2.77 \quad 1.43$

23 Sınavlarına daha az çalışıyorum

24 Birçok sınava, öğrendiklerimi sınav bitinceye kadar aklımda tutmak için çalışıyorum $3.06 \quad 1.39$

25 Sınav kâğıdını elime aldı̆̆ım zaman, sınav hakkında korkularım olduğu için başarılı $3.72 \quad 1.22$ olamiyorum

26 Sınav tarihleri ilan edildiği zamanlar tedirgin oluyorum $\quad 4.00 \quad 1.11$

\begin{tabular}{lrr}
\hline Alt ortalama & 3.44 & 0.65 \\
\hline Genel Ortalama & 3.51 & 0.45
\end{tabular}


Anketteki maddeler olumsuz ifadeleri içerdiğinden değerler yükseldikçe çalışma becerilerinin düşük olduğu sonucuna varılmaktadır. Buna göre Tablo 1'de gösterilen bulgular incelendiğinde, öğretmen adaylarının DÇBA'nin geneline ait puan ortalaması ile alt boyutlarından motivasyon ve sinavlara hazırlanma-sınav kaygısı boyutlarına sırasıyla 3.51, 3.65 ve 3.44 ortalama ile çok katıldıkları görülmüştür. Zaman yönetim boyutuna ise 3.37 ortalama ile orta derecede katılmışlardır.

Tablo 2'ye bakıldığında gerek kadınların $(\overline{\mathrm{X}}=3.55)$ gerekse erkeklerin $(\overline{\mathrm{X}}=3.47)$ anketin genelinden elde edilen puanlarına ait aritmetik ortalamalarının yüksek düzeyde olduğu görülmektedir. Anket puanları alt boyutlara göre incelendiğinde ise hemen her alt boyut için kadın ve erkek öğretmen adaylarının anketteki ifadelere yüksek düzeyde katılım gösterdikleri görülmektedir. Ayrıca yapılan t-testi sonucuna göre cinsiyetler arasında ders çalışma becerileri açısından anlamlı bir fark bulunmamıştır.

Tablo 2

Öğretmen Adaylarının DÇBA Puanlarının Cinsiyete Göre Durumları

\begin{tabular}{lccccc}
\hline Boyutlar & Cinsiyet & $\bar{X}$ & $s s$ & $t$ & $p$ \\
\hline Motivasyon & Kadın & 3.78 & 0.45 & -2.167 & $0.034^{*}$ \\
& Erkek & 3.43 & 0.84 & & 0.338 \\
\hline Zaman Yönetimi & Kadın & 3.33 & 0.50 & 0.966 & 0.505 \\
& Erkek & 3.47 & 0.61 & & 0.671 \\
\hline Sinav hazırlanma-sinav kaygisı & Kadın & 3.41 & 0.61 & & 0.527 \\
& Erkek & 3.52 & 0.73 & & -0.636 \\
\hline Anketin Geneli & Kadın & 3.55 & 0.36 & & \\
\hline
\end{tabular}

$* p<.05$

\section{Sonuç ve Tartışma}

$\mathrm{Bu}$ çalışmada biyoloji öğretmen adaylarının ders çalışma becerileri incelenmiştir. Ayrıca biyoloji öğretmen adaylarının ders çalışma becerilerinin cinsiyete göre farklılaşıp farklılaşmadığı araştırılmıştır.

Çalışmada kullanılan anketten elde edilen genel ortalama puanlarına bakıldığında biyoloji öğretmen adaylarının ders çalışma becerilerinde eksikliklerin olduğu görülmektedir. Alan yazın incelendiğinde bu çalışmanın bulgularını destekler nitelikte benzer çalışmaların bulunduğu görülmektedir (Bay ve diğerleri, 2005; Dural, 2008; Durukan, Batman \& Yiğit, 2015; Sirmac1, 2003; Temelli \& Kurt, 2010). Öğretmen adayları ile yürütülen söz konusu araştırmalarda özellikle ders çalışmaya zaman ayırdığı halde başarısız olan bu öğretmen adaylarının genellikle etkili ders çalışma stratejilerine sahip olmadıkları görülmüştür (Atılgan, 1998). Örneğin bu çalışmada öğretmen adaylarının "sınavlarıma çalışıyorum ama sınava gittiğimde aklımda konuyla ilgili hiçbir şey kalmıyor" ifadesine 3.14 ortalama ile yüksek bir katılım göstermesi alan yazındaki bulgularla paralellik taşımaktadır. Eren'in (2011) de ifade ettiği gibi burada dikkat edilmesi gereken nokta, ders çalışmada harcanan sürenin 
uzunluğunun başarıyı sağlamadığıdır. Başarılı olmanın yolu etkili ve verimli ders çalışmadır.

Çalışmanın bulguları alt boyutlar açısından değerlendirildiğinde, öğretmen adaylarının özellikle motivasyon alt boyutunda 3.65 ortalama ile ifadelere katıldıkları ve dolayısıyla motivasyonlarının düşük olduğu ortaya çıkmıştır. Biyoloji öğretmen adayları ile yapılan bazı çalışmalarda (Aluçdibi \& Ekici, 2007; Bahar, 2002; Ekici, 2010) ise öğretmen adaylarının motivasyon düzeylerinin orta düzeyde olduğu bulunmuştur. Yapılan araştırmalar aynı zamanda, motivasyon düzeyi yüksek olan öğretmen adaylarının karşılaştıkları problemlerle başa çıkmada istekli ve başarılı olduklarını, kendilerinden beklenen görevleri tamamlama konusunda kararlı olduklarını ve işlerini zevk alarak yaptıklarını göstermektedir (İlhan ve diğerleri, 2013; Masgoret \& Gardner, 2003). Dolayısıyla motivasyonu düşük olan bireylerin derslerine çalışma, dersi dinleme veya ders esnasında herhangi bir aktivitede bulunma noktasında motivasyonu yüksek olanlara göre isteksiz olmaları kaçınılmazdır (Çakmak \& Ercan, 2006). Bu nedenlerden dolayı, bilginin zihinde yapılandırılması sürecinde önemli faktörlerden birinin motivasyon olduğu (Brophy, 1998; Lee \& Brophy, 1996) ve düşük başarı düzeyine sahip öğretmen adaylarının, derse yönelik motivasyonlarının da düşük seviyede olduğu dikkate alındığında (Aluçdibi \& Ekici, 2007; Andrew \& Vialle, 1998; Pajares, 1996; Schunk, 1991) ders çalışma becerisi açısından motivasyonun önemi artmaktadır. Öte yandan bu çalışmada öğretmen adaylarının düşük motivasyon düzeyine sahip olmalarının nedenine yönelik kesin bir yargıya varmak zordur. Zira bireylerin ders çalışırken motivasyon düzeylerini etkileyen pek çok faktör vardır. Bu faktörler öğrencilerin kendisinden kaynaklanan faktörler olabileceği gibi sınıf ortamı, dersi yürüten öğretim elemanı vb. dışsal faktörlerden de kaynaklanabilir (Çetin, 2018). Bu çalışmada sadece bireyin kendinden kaynaklı motivasyon engelleri sorgulandığı için motivasyonu etkileyen diğer faktörlerin de irdelenmesine yönelik daha fazla çalışmaya ihtiyaç olduğu söylenebilir.

Zaman yönetimi boyutunda 3.37 ortalama ile biyoloji öğretmen adaylarının ifadelere orta derecede katıldıklarını savunmuşlardır. Bu durum ders çalışma becerileri açısından öğretmen adaylarının zamanı yeterince etkili bir şekilde kullanamadıklarını göstermektedir. Örneğin; öğretmen adaylarının bu alt boyutta yüksek ortalama ile katılım gösterdiği bazı ifadelere bakıldığında, sınavlara bir gün önce hazırlandıkları, belli bir plan dâhilinde çalışmadıkları veya ders çalışırken bazı derslere odaklandıklarından diğerlerine yeterince zaman ayıramadıklarını ifade ettikleri belirlenmiştir. $\mathrm{Bu}$ bulgular öğretmen adaylarının derse yönelik motivasyonun düşük olması ile ilişkili olabilir. Zira çalışmada öğretmen adaylarının motivasyon boyutuna ait ifadelere çoğunlukla katıldıkları ve bu nedenle motivasyon düzeylerinin düşük olduğu belirlenmiştir. Derse yönelik motivasyon düşük olursa, öğrenci/öğretmen adayları o derse hazırlanmak için de yeterince zaman ayırmayabilir veya zaman ayırsa bile bu zamanı etkili bir biçimde kullanamayabilir (Sırmacı, 2003; Trueman \& Hartley, 1996). $\mathrm{Bu}$ ilişkiyi destekler nitelikte Bay ve diğerleri (2005) tarafından yapılan çalışmanın sonuçları da öğrencilerin motivasyonları arttıkça, zamanı etkili biçimde kullanabilme ve sınavlara hazırlanabilme becerisinin arttığını ortaya koymuştur. Dolayısıyla zamanı tam ve doğru bir şekilde kullanmak, her basamakta olduğu gibi üniversitede öğrenim gören öğrenciler veya öğretmen adayları için de başarılı olmada büyük öneme sahiptir. Nitekim alan yazındaki birçok çalışma bu düşünceyi destekler niteliktedir (Başak, Uzun, 
\& Arslan, 2008; Çağllyan \& Güral, 2009; Kocabaş \& Erdem, 2003; Öncel, Büyüköztürk, \& Özçelikay, 2005). Öğretmen adayları ile yürütülen bazı araştırmalarda ulaşılan sonuçlar, akademik başarı ile zaman yönetimi arasında pozitif korelasyon olduğunu ortaya koymuştur (Demirtaş \& Özer, 2007; Nelson \& Nelson, 2003). Diğer taraftan öğrencilerin ders çalışma alışkanlıkları ile kaygı arasındaki ilişkiyi araştıran Aydın (1990), yapmış olduğu çalışmada; öğrenme sürecinde öğrencilerin sahip oldukları kaygı ile zamanı yönetme arasında istatistiksel olarak anlamlı düzeyde ilişkiler olduğunu belirlemiştir. Elbette etkili bir şekilde zaman yönetimi sağlamada ihtiyaçların önceden tespit edilmesi ve bu ihtiyaçları gidermeye yönelik gerekli hedeflerin oluşturulması, öncelik gerektiren işlerin tespiti vb. birtakım planlamalar yapmak, ortaya çıkabilecek problemlere karşı hazırlıklı olmada bir ön koşul olabilir (Gözel, 2010). Öte yandan zaman yönetimi ile başarı arasında pozitif bir ilişki olduğunu ortaya koyan araştırma bulguları dikkate alındığında (Campbell \& Svenson, 1992; Tektaş \& Tektaş, 2010; Trueman \& Hartley, 1996), öğrencilerde zaman yönetimine yönelik becerileri geliştirmeyi başarmaları durumunda eğitim-öğretim sürecinin sonunda kazandırılması planlanan hedeflere ulaşılmasının daha da kolay olacağı öngörülebilir.

Çalışmada elde edilen bir diğer bulguda, sınavlara hazırlanma-sınav kaygısı alt boyutunda biyoloji öğretmen adayları 3.44 ortalama ile yine ders çalışma becerilerinde birtakım eksiklikler olduğunu göz önüne sermişlerdir. Türkiye'de öğretmen adaylarındaki sınav kaygısı ile ilgili yapılan çalışmalar bu durumu destekler niteliktedir (Baştürk, 2007; Dinçer \& Akdeniz, 2008; Piji-Küçük, 2010). Çalışmada öğretmen adaylarının sınav kaygılarının yüksek düzeyde olmasının birçok sebebi olabilir. PijiKüçük'ün (2010) de ifade ettiği gibi sınava yeteri kadar hazırlanılmaması, verimli çalışma yöntemlerinin bilinmemesi, başarı beklentisinin sahip olunan yeterlik düzeyinin üzerinde olması, geçmişte yaşanan kötü sınav deneyimleri, özgüven eksikliği gibi birçok faktör, öğretmen adaylarında sınav kaygısının oluşmasının nedenleri arasında sıralanabilir. Bu çalışmada da sınavlara hazırlanma-sınav kaygısı boyutuna ait ifadelere bakıldığında öğretmen adaylarının sınavlarda başarılı olamama korkusunun ders çalışmalarını olumsuz yönde etkilediği, sınav tarihlerinin yaklaşması, sınav hakkındaki korkular vb. ifadelerde yüksek katılım gösterdikleri tespit edilmiştir. Benzer şekilde Bay ve diğerleri (2005), öğretmen adaylarının sınavlara az bir zaman kala çalışmalarının, konuların yetişmemesine ve eksik öğrenmelerine neden olduğu için sınav öncesi kayg1 düzeyinin de yüksek çıkmasına neden olduğu sonucuna ulaşmışlardır. Culler ve Holahan'a (1980) göre, sınav kaygısı yaşayan bireylerin çalışma alışkanlıkları olumsuz yönde gelişmektedir. Bunun bir sonucu olarak yoğun sınav kaygısı yaşayan öğrenciler öğretim sürecinde de düşük başarı sergilemektedirler. Bu durumu destekler nitelikte Dinçer ve Akdeniz' in (2008) yaptığı çalışmanın sonuçları, motivasyon, zaman yönetimi ve sınav kaygısının öğretmen adaylarının akademik başarısı üzerinde anlamlı etkisinin olduğunu ortaya koymuştur. Dolayısıyla sınava zamanında yeterince hazırlanmadığını düşünen bireylerin sınav kaygılarının da artış gösterebildiği söylenebilir. Erözkan'a (2004) göre başarıyı etkileyen faktörlerden birisinin bu olduğu düşünüldüğünde sınav kaygısının, aşırı fizyolojik tepkileri, yeterli düzeyde olmayan ders çalışma becerilerini ve sınav ile bağlantılı olmayan zihinsel aktiviteleri içerdiği söylenebilir. Ayrıca sınav kaygısı yüksek olan bireylerin düşük olanlara göre ders çalışma alışkanlıklarının daha yetersiz düzeyde olduğu da tespit edilmiştir. $\mathrm{Bu}$ nedenle öğretmen adaylarının sınav kaygılarını azaltmak için ders çalışma becerilerinin geliştirilmesi oldukça önemlidir. 
Çalışmada öğretmen adaylarının ders çalışma becerilerinin cinsiyet açısından farklılık gösterip göstermediği de incelenmiş ve kadınlar ile erkeklerin puan ortalamaları arasında istatistiksel olarak önemli düzeyde bir farklılık bulunmamıştır. Bu bulgu, aritmetik ortalamalar açısından da incelendiğinde erkekler ile kadınların ders çalışma becerileri açısından benzer özelliklere sahip olduklarını göstermektedir. Alan yazında ders çalışma becerileri açısından cinsiyetler arasında önemli düzeyde herhangi bir farklılığın olmadığına dair benzer bulgular mevcuttur (Bay ve diğerleri, 2005; Çoban \& Ergin, 2008; Ellez \& Sezgin, 2002; Selçuk, Çalışkan, \& Erol, 2007; Yıldız, 2010). Bununla beraber bulgulara ait alt boyutlar açısından bakıldığında motivasyon boyutunda kadınlar lehine anlamlı farklılığın olduğu ortaya çıkmıştır. Söz konusu boyutta yer alan ifadelere bakıldığında, kadınların erkeklerden daha yüksek ortalamaya sahip olmaları onların motivasyonlarının daha düşük düzeyde olduğunu ortaya koymaktadır. Alan yazında yapılan bazı çalışmalar, bu çalışmanın bulgularının aksine kadınların daha yüksek düzeyde motivasyona sahip olduğunu ortaya koyarak bunun nedenini, biyoloji alanına yönelik olarak kadınların duyuşsal özelliklerinin daha yüksek olması şeklinde açıklamaktadırlar (Aluçdibi \& Ekici, 2007; Gül, 2011). Dolayısıyla bu çalışmada biyoloji öğretmen adaylarında ders çalışma alışkanlıkları açısından kadınların erkeklerden daha düşük motivasyona sahip olmaları oldukça düşündürücüdür. Dolayısıyla bu bulgunun nedenine yönelik doğru bir açıklama yapabilmek için, biyoloji öğretmen adaylarının ders çalışma alışkanlıklarını etkileyen motivasyon gibi duyuşsal özellikler ve bunları etkileyen faktörlere yönelik daha derinlemesine çalışmaların yapılması uygun görülmektedir.

Sonuç olarak bilginin her geçen gün artarak değiştiği günümüzde, eğitimöğretim kurumlarında öğrencilere kazandırılması beklenen en önemli becerilerden biri öğrenmeyi öğrenme, bir başka ifadeyle kendi öğrenme sürecinin farkında olma ve etkili çalışma beceri ve stratejilerini kullanmadır. Dolayısıyla etkili ders çalışma becerilerinin geliştirilmesi oldukça önemlidir. Bu noktada, ders çalışma becerilerinin geliştirilmesi için aşağıdaki önerilerde bulunulabilir.

\section{Öneriler}

Çalışmanın bulguları, biyoloji öğretmen adaylarının genel olarak ders çalışma becerilerinde bazı eksikliklerin olduğunu ortaya koymaktadır. Dolayısıyla öğretim kurumlarında ders çalışma becerilerinin öğretimi daha fazla önemsenmeli, öğrencilerin hayat boyu kullanacakları bir beceri olduğundan hareketle, öğretim programlarına etkili ders çalışma stratejileri adı altında dersler konularak, öğretmen adaylarının bu konuda kendilerini uygulamaya yönelik yetiştirmeleri sağlanmalıdır (Çetin, 2018).

Konular sadece sınıfta öğrenilmez, sınıf dışında yapılan etkinliklerle de öğrenilir. Bu nedenle kendileri de henüz öğrenci konumunda olan öğretmen adaylarının ders dışındaki çalışmaları da kontrol edilmelidir. Bu bağlamda sınıf dışı etkinliklere ağırlık verilmesi yararlı olabilir. Böylece öğretmen adayları zamanı etkili kullanmayı, elverişli mekânda çalışmayı öğrenebilirler (Temelli \& Kurt, 2010).

Zamanı verimli kullanmanın ön şartı, çalışma saatlerinin bir programa bağlanmasıdır. Bu yüzden öğretmen adaylarının, daha planlı bir çalışmaya yönelmeleri, ailelerinden uzakta olanların barındığı yurtların ders çalışmaya uygun hale getirilmesi ve daha uzun süre etkili bir şekilde çalışmalarının sağlanması için gerekli önlemler alınmalıdır (Tümkaya \& Bal, 2006). 
Biyoloji öğretmen adaylarına ders çalışmak için motivasyonu artırıcı, ders içinde dikkati çekecek öğretim yapılmalı, çeşitli öğretim yöntemlerinden yararlanılarak dersler öğretilmelidir. Örneğin derslerde öğrencilerin öğrenme ve ders çalışma stratejilerine uygun etkinlikler yapılabilir. Derste kazanılan öğrenme isteği ders dışında da devam edecek, dolayısıyla ders çalışma isteği artacaktır (Sırmacı, 2003). Bunu başarmak için, öğretmen adaylarını yetiştirecek olan öğretim elemanlarının da bilim dallarına göre öğrencilerini ders çalışmaları konusunda beklenen düzeyde yönlendirebilecek, yine bilim dallarına göre ders çalışma taktikleri konusunda bilgilendirebilecek ve ders çalışma alışkanlıkları kazandırabilecek yeterliliklere sahip olmaları sağlanmalıdır (Durukan ve diğerleri, 2015).

Öğretmen adaylarının sınav kaygısını gidermede yardımcı olabilecek olan, stresle başa çıkma seminerleri verilebilir (Bay ve diğerleri, 2005).

Ayrıca, öğrencilerin ders çalışmalarını engelleyen sorunlar ve bu sorunlar için ürettikleri çözüm yolları daha ayrıntılı olarak incelenmelidir. İleriki çalışmalarda ders çalışma alışkanlıklarını etkileyen sadece kişisel faktörleri değil kültürel ve psikolojik faktörlerin de ele alınıp konu hakkında daha geniş kapsamlı bir araştırma yapılması önerilebilir (Durukan ve diğerleri, 2015). 


\section{Summary}

Because many of the topics covered by biology are abstract, it is difficult for students to perceive and understand it (Chuang \& Cheng 2003; Gül, 2011; Sebitosi, 2007; Staeck, 1995; Thompson \& Logue, 2006). One of the reasons that plays an important role in the academic achievement of the students is the study skills. Study skills are defined as, a student's ability to act in a particular way to school activities and having a certain behavior model in this subject (İlhan, Çetin, \& Sünkür, 2013). Study skills include in a three-dimensional structure: motivation, time management, and exam preparation-test anxiety management (Bay, Tuğluk \& Gençdoğan, 2004). Motivation is a driving force for students to reach success, to work regularly in school, and to learn (Martin, 2001). Time management, the second dimension of study skills, is the ability to use efficiently a certain period of time (Açıkalın, 1994; Efil, 2000). Another dimension of study skills is the management of preparation to examinations- test anxiety. Individuals with high test anxiety tend to go to the professions with lower status, less evaluation and less competition (Ergene, 1994; Özay-Köse, Diken, \& Gül, 2017). The students are required to obtain effective study skills to reach the desired level of biology achievement. To cope with this situation, it must be determined whether the prospective teachers and teachers play an important role in helping the students obtain study skills, obtain these skills themselves in education process. Because they will teach future generations, their qualifications and abilities in this subject should be developed (Durukan, Batman, \& Yiğit, 2015).

Purpose and Significance: As stated in literature, biology lessons, due to composing of abstract concepts, are one of the courses in which the students have difficulty in understanding, learning, indicating low achievement. However, one of the reasons that play an active role in the students' success is the study skills. Therefore, it has a vital importance to develop students' study skills positively for providing the achievement and positive motivation and attitude towards biology. In this perspective, this study aims to determine the prospective biology teachers' study skills and to compare in terms of gender.

Methods: In survey study, the researcher applies a questionnaire to the participants or has an interview or interviews to collect information regarding with studied subject. Surveys are used to learn about people's beliefs, attitudes, demographics, behavior, opinions, ideas etc. (McMillan \& Schumacher, 2010). The sample of the study, which was implemented with survey method, consisted of 62 prospective biology teachers (40 females, 22 males) studying in Education Faculty of Ataturk University. For determining the teacher candidates' study skills, the data were collected through 'Study Skill Questionnaire (SSQ) developed by Bay, Tuğluk and Gençdoğan (2004). The fivepoint Likert type SSQ included in totally 26 items with three subdimensions: (1) motivation (2) time management (3) preparation for exams-test anxiety. Cronbach's Alpha for the overall scale was founded as 0.729 .

Results: The findings indicated that the prospective biology teachers had low level of study skills for all sub-dimensions of the SSQ. Additionally, the findings for overall 
SSQ indicated that there wasn't a statistically important difference between females and males in terms of gender. When the findings were compared in terms of subdimensions, there wasn't a statistically significance for gender except for sub-dimension "motivation".

Discussion and Conclusions: When the general average scores of the questionnaire used in the study are considered, it seems that prospective biology teachers have deficiencies in the study skills. When it is emphasized that motivation is one of the key components of knowledge building in the mind (Brophy, 1998, Lee \& Brophy, 1996) and that the students with low achievements have also low motivational beliefs (Aluçdibi \& Ekici, 2007; Andrew \& Vialle, 1998; Pajares, 1996; Schunk, 1991), the importance of motivation in terms of study skills is increasing. Additionally, the study was founded that males and females have similar features in terms of study skills. These findings are similar to the findings of the other studies. In the light of these findings, it can be said that the development of effective study skills is very important. As a result, following recommendations are suggested towards development of the prospective teachers' study skills. Seminars, conferences should be given to develop the teaching and learning skills of the prospective teachers and even guidance should be given in the lessons. In addition to the situation surveys to improve students' study skills, detailed investigations should be implemented to collect experimental or qualitative data. The study skills of the prospective teachers studying in other areas can also be determined. 


\section{Kaynakça}

Açıkalın, A. (1994). Teknik ve toplumsal yönleriyle okul yöneticiliği. Pegem A Yayınlar1: Ankara.

Akpınar, E. (2006). Fen ögretiminde soyut kavramların yapılandırılmasında bilgisayar desteği: yaşamımızı yönlendiren elektrik ünitesi (Yayımlanmamış doktora tezi). Dokuz Eylül Üniversitesi, Eğitim Bilimleri Enstitüsü, İzmir.

Altunoğlu, B.D., \& Atav, E. (2005). Daha etkili bir biyoloji öğretimi için öğretmen beklentileri. Hacettepe Üniversitesi Ĕ̆itim Fakültesi Dergisi, 28, 19-28.

Aluçdibi, F., \& Ekici, G. (2007). Ortaöğretim öğrencilerinin biyoloji dersi motivasyon düzeylerinin farklı değişkenlere göre incelenmesi. Abant İzzet Baysal Üniversitesi Ĕ̈itim Fakültesi Dergisi, 12(1), 197-226.

Andrew, S., \& Vilalle, W. (1998). Nursing students' self-efficacy, self-regulated learning and academic performance in science teaching. Retrieved February 03, 2009 from http://www.aare.edu.au/98pap/abs98.html.

Atılgan, M. (1998). Üniversite öğrencilerinin ders çalışma alışkanlıkları ile akademik başarılarının karşılaş̧ırılması (Yayımlanmamış yüksek lisans tezi). Gaziantep Üniversitesi, Sosyal Bilimler Enstitüsü, Gaziantep.

Aydın, B. (1990). Üniversite öğrencilerinin kaygı düzeyleri ile ders çalışma tutum ve alışkanlıklarının incelenmesi. Psikoloji Dergisi, 7(25), 33-40.

Bahar, M. (2002). Biyoloji öğrencilerinin motivasyon tarzlarının tespiti. Gazi Eğitim Fakültesi Dergisi, 22(2), 23-34.

Başak, T., Uzun, Ş., \& Arslan, F. (2008). Hemşirelik yüksekokulu öğrencilerinin zaman yönetimi becerileri. TAF Preventive Medicine Bulletin, 7(5), 429-434.

Baştürk, R. (2007). Kamu personeli seçme sınavına hazırlanan öğretmen adaylarının sinav kaygı düzeylerinin incelenmesi. Firat Üniversitesi Sosyal Bilimler Dergisi, 17(2), 163-176.

Bay, E., Tuğluk, M.N., \& Gençdoğan, B. (2004). Üniversite öğrencilerinin ders çalışma becerilerinin incelenmesi. Türk Fen Eğitimi Dergisi, 2(2), 223-234.

Bay, E., Tuğluk, M. N., \& Gençdoğan, B. (2005). Üniversite öğrencilerinin ders çalışma becerilerinin incelenmesi: Kazım Karabekir Eğitim Fakültesi Örneği. Elektronik Sosyal Bilimler Dergisi, 14, 94- 105.

Bilge, A., \& Pektaş, İ. (2004). Öğrencilerin sosyo-kültürel özellikleri, durumluk/sürekli anksiyete düzeyleri ve başa çıkma becerilerinin incelenmesi. Ege Üniversitesi Hemşirelik Yüksek Okulu Dergisi, 20(1), 47-55.

Brophy, J. (1998). Motivating students to learn. Washington: McGraw Hill.

Campbell, R. L., \& Svenson, L. W. (1992). Perceived level of stress among university undergraduate students in Edmonton. Canada. Perceptual and Motor Skills, 75(2), 552-554.

Campbell, L.A. (2004). As strong as the weakest link: Urban high school dropout. High School Journal, 87(2), 16-24.

Christenson, S.L., \& Thurlow, M.L. (2004). School dropouts: Prevention considetrations, interventions and challenges. Current Directions in Psychological Science, 13, 36-39. 
Chuang, H. F., \& Cheng, Y. J. (2003). A study on attitudes toward biology and learning environment of the seventh grade students. Chinese Journal of Science Education, 11(2), 171-194.

Culler, R. E., \& Holahan, C. I. (1980). Test anxiety and academic performance: The effects of study related behaviors. Journal of Educational Psychology, 72, 16-20.

Çağlıyan, V., \& Güral, R. (2009). Zaman yönetimi becerileri: Meslek yüksekokulu öğrencileri üzerine bir değerlendirme. Karamanoğlu Mehmetbey Üniversitesi Sosyal ve Ekonomik Araştırmalar Dergisi, 2, 174-189.

Çakmak, M., \& Ercan, L. (2006). Views of experienced and student teachers about motivation in effective teaching process. Gazi Eğitim Fakültesi Dergisi, 26(3), 133143.

Çetin, F. (2018). Öğretmen adaylarının stratejik ders çalışma eğilimlerinin incelenmesi. İnsan ve Toplum Bilimleri Araştırmaları Dergisi, 7(2), 898-921.

Çoban, G., \& Ergin, Ö. (2008). İlköğretim öğrencilerinin feni öğrenme yaklaşımları. Uludă̆ Üniversitesi Eğitim Fakültesi Dergisi, 21(2), 271-293.

Demirtaş, H., \& Özer, N. (2007). Öğretmen adaylarının zaman yönetimi becerileri ile akademik başarısı arasındaki ilişkisi. Eğitimde Politika Analizleri ve Stratejik Araştırmalar Dergisi, 2(1), 34-47.

Dinçer, G. T., \& Akdeniz, A. R. (2008). Determining the study skills of student teachers. Oral presentation at the XIII. IOSTE The Use of Science and Technology Education for Peace and Sustainable Development Symposium. Kuşadası.

Dural, Songül. (2008). Sınıf ögretmeni adaylarının öğrenme ve ders çalışma stratejileri ile başarıları arasındaki ilişki (Yayımlanmış yüksek lisans tezi). Adnan Menderes Üniversitesi, Sosyal Bilimler Enstitüsü, Aydın.

Durukan, Ü. G., Batman, D., \& Yiğit, N. (2015). Öğretmen adaylarının ders çalışma alışkanlıkları. İnönü Üniversitesi Eğitim Fakültesi Dergisi, 16(1), 63-80.

Efil, İ. (2000). Sinıf yönetimi (Ed. L. Küçükahmet). Nobel Yayıncılık: Ankara.

Ekici, G. (2010). Factors affecting biology lesson motivation of high school students. Procedia Social Behavioral Sciences, 2(2), 2137-2142.

Ellez, M., \& Sezgin, G. (2002, Eylül 16). Öğretmen adaylarının öğrenme yaklaşımları. V. Ulusal Fen Bilimleri ve Matematik Eğitimi Kongresi'nde sunulan bildiri. Alıntılama tarihi: 10 Aralık 2012.http://www.fedu.metu.edu.tr/ufbmek5/b_kitabi/PDF/OgretmenYetistirme/Bildiri/t288.

Erdamar, G. (2010). Öğretmen adaylarının ders çalışma stratejilerini etkileyen bazı değişkenler. Hacettepe Üniversitesi Ĕ̆itim Fakültesi Dergisi, 38(38), 82-93.

Eren, O. (2011). İlköğretim 6., 7. ve 8. Sinıf öğrencilerinin ders çalışma alışkanlıkları ile fen ve teknoloji dersi akademik başarıları arasındaki ilişki (Yayımlanmamış yüksek lisans tezi). Ankara Üniversitesi, Ankara.

Ergene, T. (1994). Sınav kaygısı ile başa çıkma programının etkililiği. Psikiyatri Psikoloji ve Psikofarmakoloji Dergisi, 2(1), 36-42.

Erözkan, A. (2011). Üniversite Öğrencilerinin Sınav Kaygısı ve Başa Çıkma Davranışları. Sosyal ve Beşeri Bilimler Araştırmaları Dergisi,1(12), 13-38. 
Ertem, H. (2006). Ortaöğretim öğrencilerinin kimya derslerine yönelik güdülenme tür (içsel ve dışsal) ve düzeylerinin bazı değişkenler açısından incelenmesi (Yüksek lisans tezi). Balıkesir Üniversitesi, Fen Bilimleri Enstitüsü, Balıkesir.

Gözel, E. (2010). İlköğretim okulu öğretmenlerinin zaman yönetimi hakkındaki görüşlerinin bazı değişkenler açısından incelenmesi. Muğla Üniversitesi Sosyal Bilimler Enstitüsü Dergisi, 24, 67-84.

Gül, Ş. (2011). 5E modeline dayalı olarak hazırlanan ders yazılımının öğrencilerin başarılarına, tutumlarına ve kavram yanılgılarının giderilmesine etkisi (Yayımlanmamış doktora tezi). Atatürk Üniversitesi, Eğitim Bilimleri Enstitüsü, Erzurum.

Güler, M. H., \& Sağlam, N. (2002). Biyoloji öğretiminde bilgisayar destekli öğretimin ve çalışma yapraklarının öğrencilerin başarısı ve bilgisayara karşı tutumlarına etkileri. Hacettepe Üniversitesi Eğitim Fakültesi Dergisi, 23, 117-126.

Güneri, O. Y. (1996). Durumluk ve sürekli kaygı ile sınav arasındaki ilişki. III. Ulusal Psikolojik Danışma ve Rehberlik Kongresi, Çukurova Üniversitesi, Adana'da sunuldu.

İlhan, M., Çetin, B., \& Sünkür, M. Ö. (2013). Olumlu ve olumsuz mükemmeliyetçilik ile ders çalışma becerileri arasındaki ilişkinin kanonik korelasyon ile incelenmesi. Uluslararasi Ínsan Bilimleri Dergisi, 10(1), 47-73.

Kılıç, D., \& Sağlam, N. (2004). Biyoloji eğitiminde kavram haritalarının öğrenme başarısına ve kalıcılığına etkisi. Hacettepe Üniversitesi Eğitim Fakültesi Dergisi, $27,155-164$.

Kocabaş, İ., \& Erdem, R. (2003). Yönetici adayı öğretmenlerin kişisel zaman yönetimi davranışları. Fırat Üniversitesi Sosyal Bilimler Dergisi, 13(2), 192- 202.

Lee, O., \& Brophy, J. (1996). Motivational patterns observed in sixth-grade science classroom. Journal of Research in Science Teaching, 33(3), 303-318.

Martin, A. J. (2001). The student motivationscale: A tool for measuring and enhancing motivation. Australian Journal of Guidance and Counselling, 11, 11-20.

Masgoret, A. M., \& Gardner, R. C. (2003). Attitudes, motivation, and second language learning: A meta-analysis of studies conducted by Gardner and associates. Language Learning, 53(1), 123-163.

McMillan, J. H., \& Schumacher, S. (2010). Research in education: Evidence-based inquiry (7th Ed.). London: Pearson.

Nelson, D. B., \& Nelson, K. W. (2003, March). Emotional intelligence skills: Significant factors in freshmen achievement and retention. Paper presented at the American Counselling Association Conference, Anaheim, CA.

Öncel, C., Büyüköztürk, Ş., \& Özçelikay, G. (2005). Serbest eczacıların zaman yönetimi. Ankara Eczacılık Fakültesi Dergisi, 34(3), 191-206.

Özay-Köse, E., Diken, E. H., \& Gül, Ş. (2017). Biyoloji öğretmen adaylarındaki tükenmişlik ve KPSS kaygı düzeylerinin çeşitli değişkenler açısından incelenmesi. Gazi Ĕ̆itim Dergisi, 37(3), 991-1012.

Pajares, F. (1996). Self-efficacy beliefs in academic settings. Review of Educational Research, 66(4), 543-578. 
Piji-Küçük, D. (2010). Müzik öğretmeni adaylarının sınav kaygısı, benlik saygısı ve çalg1 başarıları arasındaki ilişkinin incelenmesi. Ahi Evran Üniversitesi Eğitim Fakültesi Dergisi, 11(3), 37-50.

Rafoth, M.A., \& DeFabo, L. (1990). Study skills. What research says to the teacher. West Haven, Connecticut: NEA Professional Library, ED 323184

Schunk, D. H. (1991). Self-efficacy and academic motivation. Educational Psychologist, 26(3\&4), 207-231.

Sebitosi, E. K. (2007). Understanding genetics and inheritance in rural schools. Journal of Biological Education, 41(2), 56-61.

Selçuk, G., Çalışkan, S., \& Erol, M. (2007). Evaluation of learning approaches for prospective physics teachers. Gazi Eğitim Fakültesi Dergisi, 27(2), 25-41.

Sırmacı, N. (2003). Matematik öğretmenliği anabilim dalı öğrencilerinin ders çalışma alışkanlıklarının farklı değişkenler açısından incelenmesi. Kastamonu Eğitim Dergisi, 11(2), 359-366.

Smythe, J. A. F., \& Robertson, I. T. (1999). On the relationship between time management and time estimation. British Journal of Psychology, 90.

Softa, H. K., Karaahmetoğlu, G. U., \& Çabuk, F. (2015). Lise son sınıf öğrencilerinin sınav kaygısı ve etkileyen faktörlerin incelenmesi. Kastamonu Ĕ̆itim Dergisi, 23(4), 1481-1494.

Staeck, L. (1995). Perspectives for biological education-challenge for biology instruction at the and of the 20th century. Hacettepe Üniversitesi Ë̆itim Fakültesi Dergisi, 11, 29-35.

Taşpınar, M. (2007). Kuramdan uygulamaya öğretim ilke ve yöntemleri. Nobel Yayınları: Ankara.

Tekkaya, C., Çapa, Y., \& Yılmaz, Ö. (2000). Biyoloji öğretmen adaylarının genel biyoloji konularındaki kavram yanılgıları. Hacettepe Üniversitesi Eğitim Fakültesi Dergisi, 18, 140-147.

Tektaş, M., \& Tektaş, N. (2010). Meslek yüksekokulu öğrencilerinin zaman yönetimi ve akademik başarıları arasındaki ilişki. Selçuk Üniversitesi Sosyal Bilimler Enstitüsü Dergisi, 23, 221-229.

Temelli, A., \& Kurt, M. (2010). Eğitim fakültesi ve fen fakültesi biyoloji öğrencilerinin ders çalışma alışkanlıklarının farklı değişkenler açısından incelenmesi. Kuramsal Eğitimbilim, 3(2), 27-36.

Tezbaşaran, A. A. (1997). Likert tipi ölçek geliştirme kılavuzu (ikinci baskl). Türk Psikologlar Derneği Yayınları: Ankara.

Thomas, A. (1993). Study Skills. Eugene, Oregon: Oregon School Study Council, University of Oregon. (Eric Document Reproduction Service) ED 355616.

Thompson, F., \& Logue, S. (2006). An exploration of common student misconceptions in science. International Education Journal, 7(4), 553-559.

Topkaya, N., Yaka, B., \& Öğretmen, T. (2011). Öğrenme ve ders çalışma yaklaşımları envanteri'nin uyarlanması ve ilgili yapılarla ilişkisinin incelenmesi. Eğitim ve Bilim, 36(159), 192-204. 
Trueman, M., \& Hartley, J. (1996). A comparison between the time management skills and academic performance of mature and traditional-entry university students. Higher Education, 32, 199-215.

Tümkaya, S., \& Bal, L. (2006). Çukurova üniversitesi öğrencilerinin ders çalışma alışkanlıklarının bazı değişkenler açısından incelenmesi. Çukurova Üniversitesi Sosyal Bilimler Enstitüsü Dergisi, 15(2), 313-326.

Uluğ, F. (1981). Verimli çalışma alışkanlıkları kazandırma konusunda yapılan rehberliğin okul başarısına etkisi (Yayımlanmamış yüksek lisans tezi). Ankara Üniversitesi, Ankara.

Ünal, G., \& Ergin, Ö., 2006. Buluş yoluyla fen öğretiminin öğrencilerin akademik başarılarına, öğrenme yaklaşımlarına ve tutumlarına etkisi. Türk Fen Eğitimi Dergisi, 3(1), 37-52.

Yaman, M., \& Soran, H. (2000). Türkiye'de ortaöğretim kurumlarında biyoloji öğretiminin değerlendirilmesi. Hacettepe Üniversitesi Ĕ̆itim Fakültesi Dergisi, 18, 229-237.

Yıldız, H. (2010, Mayıs 13). Öğretmen adaylarının sahip oldukları ögrenme stilleri ve öğrenme yaklaşımları arasındaki ilişki. Birinci Ulusal Eğitim Programı ve Öğretimi Kongresi'nde sunulan bildiri. Alıntılama tarihi: 10 Aralı 2012. http://www.pegem.net/akademi/kongrebildiri detay.aspx?id=117841.

Yılmaz, M. B., \& Orhan, F. (2011). Ders çalışma yaklaşımları ölçeğinin Türkçe formunun geçerlik ve güvenirlik çalışması. Eğitim ve Bilim, 159(36), 69-83.

This is an Open Access article distributed under the terms of the Creative CommonsAttributionNonCommercial-ShareAlike 4.0 International (CC BY-NC-SA 4.0). For further information, you can refer to https://creativecommons.org/licenses/by-nc-sa/4.0/ 